\title{
Expertise e Participação da População em Contexto de Risco Nuclear: Democracia e Licenciamento Ambiental de Angra 3
}

Gláucia Silva

\section{INTRODUÇÃO}

o presente artigo, o objetivo é discutir a especificidade da partici-
pação de cidadãos com relação ao monitoramento dos riscos tecnológicos, especialmente o "risco nuclear", com base em uma situação empírica, qual seja, a audiência pública para o licenciamento ambiental da usina nuclear Angra 3, terceira unidade da Central Nuclear Almirante Álvaro Alberto (CNAAA), situada no município de Angra dos Reis, no Rio de Janeiro.

As audiências públicas para o licenciamento de atividades poluidoras, bem como os estudos de impacto ambiental (os chamados EIA), passaram a ser procedimentos exigidos por lei a partir de 1986, quando o Conselho Nacional do Meio Ambiente (Conama) instituiu política nacional compreendendo a avaliação de impactos ambientais. Assim, a audiência pública visa permitir ao órgão licenciador - no caso, o Instituto Brasileiro de Meio Ambiente (Ibama) - um diagnóstico dos impactos que o empreendimento pode causar. Durante a audiência, a população e setores do poder público se manifestam, e o Ibama pode concluir pela concessão ou pela negação da licença ambiental.

Ao longo de 2007 ocorreram quatro audiências públicas para o licenciamento ambiental prévio da usina nuclear Angra 3, todas com o mes-

DADOS - Revista de Ciências Sociais, Rio de Janeiro, Vol. 52, nº3, 2009, pp. 771 a 805. 
mo teor, objetivando a discussão do Relatório do Estudo de Impactos Ambientais sobre a implementação dessa unidade ${ }^{1}$. Estive presente na quarta audiência pública, ocorrida em 26 de novembro de 2007 na cidade do Rio de Janeiro, a que me refiro constantemente ao longo deste texto ${ }^{2}$.

A especificidade sobre a qual versa o presente artigo, e que foi expressa na demanda favorável ao monitoramento, por parte da população, do funcionamento das atividades da central nuclear, surgida ao longo das audiências públicas para o licenciamento de Angra 3, diz respeito ao fato de esse acompanhamento implicar necessariamente a mediação de um experto, já que o tipo de poluição produzido por uma usina nuclear - a radiatividade - não é perceptível pelos sentidos. Para sua detecção e aferição, é necessária a intervenção de um técnico com seus instrumentos de medida - os "órgãos sensoriais da ciência" (Beck, 2001:355). Somente assim podem ser atestadas a presença e a quantidade de determinados átomos. É essa forma de mensuração, com peritos e instrumentos adequados, que faz a eventual desconfiança sobre o mau funcionamento de uma usina ultrapassar o plano da suspeita. Assim, a participação requerida pela vigilância dos riscos nucleares não pode dispensar o recurso à expertise (e também à contraexpertise), já que, ao contrário do que encontramos no exercício da "ciência do concreto" (Lévi-Strauss, 1976), os sentidos (olfato, tato, paladar, audição e visão) são ineficazes para o estabelecimento de critérios classificatórios.

Um dos temas predominantes na audiência pública para o licenciamento de Angra 2 foi a fragilidade do Plano de Emergência Externo (PEE) (Leite Lopes et alii, 2006), imprescindível para a concessão da licença para a operação das usinas. O mau estado da estrada (Rodovia Rio-Santos, BR-101) que permitiria a evacuação da população circunvizinha à central, em caso de pane, era realmente um tendão de Aquiles, capaz de inviabilizar a licença ambiental que foi concedida sob a condição de as obras serem feitas na rodovia. A análise desse processo e a detalhada etnografia sobre tal audiência podem ser encontradas em estudo anterior (idem, ibidem), que evidenciou como o prefeito da cidade de Angra dos Reis soube fazer do problema do Plano de Emergência um motivo para que a empresa se dispusesse a dialogar com associações locais e com a própria prefeitura. 
Na medida em que o espaço de uma audiência pública é utilizado essencialmente pelas associações de moradores e pela população para que requeiram serviços urbanos que o poder público não dá conta de prestar, a existência do risco fica secundarizada. Embora o PEE evoque a existência de um risco, as discussões ocorridas por ocasião do licenciamento de Angra 2 diziam respeito ao bom estado da estrada, de grande importância para o município, e não a algum aspecto substantivo do Plano. Pleitear a favor de um controle popular sobre o funcionamento das usinas é ver, no risco, uma questão em si, e não apenas um meio de melhorar condições de vida. Assim, o presente texto considera que a demanda por controle social, o que torna imprescindível a mediação de um experto, significa uma mudança na forma dessa participação que, ao exigir a possibilidade de acompanhar a operação da central, acaba por "desnaturalizar" (Leite Lopes et alii, 2000; Leite Lopes, 2004; Leite Lopes, 2006) a existência do risco nuclear. Para a construção de tal argumento, as formas de controle social engendradas na França servirão de contraponto (ver Silva, 2007).

Neste artigo, é considerado ainda que discutir a mudança na qualidade da participação implica lidar com a questão teórica evocada pelo papel do experto em contendas desse tipo. Com base em diversos autores, longe de ver o experto como um porta-voz da ciência, sem nenhum viés ideológico ou político, será mostrado, por um lado, como o exercício da expertise evidencia a perda do monopólio da produção da verdade por parte da ciência; por outro, como os expertos se tornam partes indispensáveis em disputas de interesses.

As audiências públicas para a construção de Angra 3 constituíram um procedimento posterior a todo um complexo processo decisório cuja análise está para além do escopo deste estudo, envolvendo diversos agentes formuladores de políticas nacionais para o setor nuclear, culminando na aprovação da construção da mencionada usina pela Comissão Nacional de Política Energética Nuclear. Também não é meu intuito, neste artigo, mapear todas as posições e esboçar uma etnografia nos moldes do que já foi feito sobre o licenciamento de Angra 2 (Leite Lopes et alii, 2006), pois, por um lado, a delimitação do objeto do presente texto se perderia e, por outro, seria um esforço redundante na medida em que há grande semelhança entre ambos os contextos. Por exemplo, a audiência pública para o licenciamento de Angra 3, bem como a relativa à Angra 2, foi organizada para viabilizar o projeto a ser licenciado, e em ambas o empreendedor amenizou os impactos negati- 
vos (idem, ibidem:371). O regulamento dos eventos foi igualmente idealizado a fim de evitar a discussão ideológica e favorecer o discurso considerado "puramente técnico", como se este último pudesse existir independentemente da dimensão política. Em estudos anteriores, verificou-se que tal embate é, mesmo, cuidadosamente evitado por seus promotores nesse tipo de evento, seja no Brasil (Leite Lopes et alii, 2006), seja na França (Silva, 2007).

A grande diferença entre as duas situações é que, nas audiências relativas à Angra 3, surgiu, como já mencionado, um novo tema, de caráter nitidamente político, ou seja, a demanda por um controle social do funcionamento da central. Essa novidade propicia reflexões sobre a adoção desse tipo de tecnologia relacionadas tanto ao tipo de poluição que ela provoca quanto às possibilidades de setores da população se articularem com cientistas que sirvam de mediadores no monitoramento das atividades das usinas nucleares brasileiras.

\section{AS AUDIÊNCIAS PARA AS ANGRAS: DA COMPENSAÇÃO AMBIENTAL AO CONTROLE SOCIAL}

O Brasil vem construindo, desde a década de 1970, sua central nuclear, denominada Almirante Álvaro Alberto e localizada no município de Angra dos Reis ${ }^{3}$, que, além de dispor de outras indústrias de grande porte, apresenta também a singularidade de, nas últimas décadas, ter sido palco de diversas experiências consideradas "participativas", como o plano diretor da cidade ${ }^{4}$ e a implementação de uma Agenda 21, bem-sucedida em um primeiro momento. A central possui duas usinas - Angra 1 e Angra 2 - e empreende as obras de Angra 3, última unidade prevista para o sítio.

A operação das usinas nucleoelétricas nacionais esteve, até agosto de 1997, a cargo de Furnas Centrais Elétricas S.A., empresa criada em 1957 e que, inicialmente, foi incluída no programa de privatização lançado na década de 1990 pelo governo Fernando Henrique Cardoso (1995-2002). As atividades nucleares são monopólio do Estado, garantido pela Constituição Federal, e o setor não foi incluído no plano de privatização. A diretoria nuclear de Furnas foi então desmembrada, originando a empresa de capital misto - "estatal" - Eletronuclear (ETN), que, além do setor nuclear de Furnas, incorporou a Nuclebrás Engenharia (Nuclen) ${ }^{5}$. Apesar de Furnas não ter sido privatizada, a 
ETN se estabeleceu como uma empresa independente e cuja criação é entendida como uma conquista importante por seus funcionários:

Para o setor nuclear foi extremamente importante a existência da Eletronuclear. O setor nuclear era um patinho feio em Furnas. Hoje é uma grande empresa e efetivamente conseguiu concluir a unidade 2. Provavelmente, se não tivesse sido criada a empresa, levaria muito mais tempo para construir esta unidade. Então, para o setor nuclear, foi importante criar a empresa e ainda para nossa sorte não conseguiram privatizar Furnas. A empresa tem problema financeiro; quando houve a cisão, estabeleceu uma tarifa abaixo das suas necessidades. Isso é um problema, mas na verdade a tarifa só foi estabelecida para bancar o custo de operação. Então nunca houve risco na operação da usina. Agora o problema é que tem outros custos. Nós somos agora uma empresa subsidiária da Eletrobrás; como é Furnas (depoimento de um alto funcionário da $\mathrm{ETN})^{6}$.

No momento inicial de sua construção, a CNAAA foi considerada por seus promotores um projeto benéfico para o "desenvolvimento" do país e da região. Essa ideia foi suficiente para que o governo militar decidisse por sua instalação (cf. Oliveira, 1989; Malheiros, 1993). Entretanto, na década de 1980, com a aprovação da legislação ambiental e a criação do Conama, a ETN teve de começar a lidar com uma nova maneira de aprovar seus empreendimentos ${ }^{7}$. Para o licenciamento de Angra 2, que entrou em operação em janeiro de 2001, a empresa se submeteu a procedimentos inexistentes em 1985, quando Angra 1 foi inaugurada. A Lei Orgânica do Município de Angra dos Reis, reformulada em 1990, passou a estabelecer que novas usinas, para serem instaladas ali, deveriam requerer à municipalidade alvará de licença para funcionamento.

O município não recebia da central nuclear, de propriedade de uma empresa estatal, que tanto havia alterado seu cenário, nenhum tipo de contribuição financeira. O primeiro prefeito a buscar uma fórmula que amenizasse tal ausência foi João Luiz Gibrail (1983-1985). Furnas (por meio da diretoria que hoje compõe a ETN) passou a manter "convênios" com a prefeitura de Angra dos Reis, renovados, com algumas interrupções, desde a gestão de Gibrail.

A empresa assinou inicialmente um convênio de cooperação objetivando a organização da Defesa Civil do município, em função do Plano de Emergência, necessário para remediar casos de acidentes com 
vazamento radiativo. Visava também auxiliar a municipalidade na promoção de infraestrutura (postos médicos, escolas e rede de esgoto sanitário) em povoados próximos à central nuclear - Frade, Mambucaba e Perequê. Assim, o convênio se convertia na solução de problemas criados, pelo menos em parte, pela própria instalação da central.

Do início de sua construção, quando se apresentava somente em seus aspectos positivos, associados ao "desenvolvimento", até a assinatura desse primeiro acordo, houve um crescente reconhecimento de que aspectos "negativos" também acompanhavam a instalação das usinas no local. Embora os mais sentidos fossem de ordem urbanística, causados pelo afluxo de imigrantes de outras cidades e estados brasileiros que vinham se empregar como trabalhadores da construção civil, havia o risco nuclear propriamente dito, que não recebia a mesma atenção. $\mathrm{O}$ PEE, por exemplo, só recebeu um tratamento mais cuidadoso quando da construção de Angra 2, por exigência da nova legislação.

Quando Neirobis Nagae, membro do Partido dos Trabalhadores (PT) e militante político egresso do movimento ambientalista e antinuclear local, foi eleito prefeito de Angra dos Reis (1989-1992), preocupou-se em exigir um Plano de Emergência exequível. Entretanto, a pretexto de seu passado político, a central suspendeu os convênios que mantivera até então com a prefeitura e só lentamente voltou atrás. Na gestão seguinte, o prefeito que o sucedeu, Luiz Sergio Nóbrega de Oliveira (1993-1996), também do PT, assinou com a ETN (Furnas, na época) convênio de valor maior (cf. Ribeiro, 2005:84). A prefeitura, por sua vez, pediu a assessoria da Coordenação dos Programas de Pós-Graduação em Engenharia (Coppe - atual Instituto Alberto Luiz Coimbra de Pós-Graduação em Engenharia)/Universidade Federal do Rio de Janeiro (UFRJ) para propor uma reformulação do PEE.

Por um lado, uma nova legislação, que garante a participação da municipalidade e da população no processo de licenciamento; por outro, os mencionados convênios, que podem ser suspensos a qualquer instante. Ambos criaram um contexto ideal para negociações entre prefeitura, população em geral e empresa em momentos de expansão da central. Assim, quando se começava a construção de Angra 2, a prefeitura pôde embargar, judicialmente, as obras civis, apoiando-se no fato de que legisla sobre o território do município. A empresa teve então de entrar com um pedido de licença de construção na prefeitura e se submeteu ao processo de licenciamento exigido por lei. Com provas de força 
de ambos os lados, empresa e municipalidade iniciaram, na época, um novo entendimento, em que esta última exigia ressarcimento dos "impactos", por meio de outros "convênios", e exequibilidade para o PEE, ao passo que a primeira conquistava a ampliação de suas instalações.

No entanto, observa-se que, enquanto a existência de impactos urbanos negativos foi sendo admitida ao longo do tempo pelos diretores da empresa, não se estabeleceu nenhum tipo de taxa obrigatória (royalties, por exemplo) a ser paga à municipalidade. Para alguns vereadores e líderes locais, uma cobrança desse tipo seria uma forma de amenizar os chamados impactos urbanos. Ainda em 1999, objetivando sensibilizar o Congresso Nacional para a assinatura de lei que estipulasse o pagamento de royalties pela central, a comissão municipal de meio ambiente angrense promoveu um fórum de debates específico para essa discussão com congressistas, no qual os deputados Laura Carneiro (Partido da Frente Liberal - PFL) e Antônio Feijão (Partido da Social Democracia Brasileira - PSDB) estiveram presentes, sem ter tido, entretanto, nenhum resultado prático.

O instrumento de "compensação ambiental", conforme o que estabelece o Ibama ao longo do processo de licenciamento ambiental, refere-se à aplicação de um percentual da receita da indústria na manutenção de reservas indígenas e de unidades de conservação ${ }^{8}$, nada estipulando com relação aos chamados problemas urbanos do município. A empresa argumenta que cumpre rigorosamente a lei destinando um percentual de sua receita para o financiamento de áreas de preservação e conservação.

Assim, não existindo nenhum dispositivo legal que regulamente especificamente uma forma de amenizar os chamados impactos urbanos, há o constante empenho por parte dos prefeitos na tentativa de substituir os convênios (opcionais) por taxas ou impostos (obrigatórios), âmago da tensão existente entre central nuclear e prefeitura. Após três mandatos do PT, a eleição de um prefeito do Partido do Movimento Democrático Brasileiro (PMDB), Fernando Antônio Ceciliano, para o período 2001-2004, reeleito para 2004-2008, não alterou a tensão existente com a continuidade ou não dos 22 convênios firmados entre empresa e prefeitura em mandatos anteriores.

Antes mesmo dos acordos sucessivos com o município, a CNAAA, ao ser instalada, já havia construído, na década de 1970, colégios e postos 
de atendimento médico para os moradores das vilas residenciais. Ainda hoje, os dois colégios estaduais são mantidos pela central, e o hospital de Praia Brava - atualmente uma fundação - passou a integrar o Sistema Único de Saúde (SUS), complementando as ações da rede municipal de saúde. Esses serviços foram assim gradualmente sendo abertos aos habitantes das comunidades vizinhas, conforme o estabelecido em um dos convênios assinados. Portanto, o que era destinado inicialmente ao atendimento de seus empregados passou a ser incorporado ao conjunto de benfeitorias - ou de "contrapartidas" - que a empresa dirige à população angrense e é sempre objeto de renegociação em momentos de ampliação da central.

Nos últimos sete anos, visando a uma maior aceitação de sua presença no local, a ETN tem buscado se aproximar diretamente da população por meio de uma prática denominada "atendimento". A empresa financia iniciativas locais, tais como camisetas para times de futebol, ônibus para excursões escolares e festividades diversas. Pesquisas sobre os programas de responsabilidade social da empresa (Ribeiro, 2005) evidenciam que, embora pouco enfatizado ou divulgado, um importante critério para a aprovação dos pedidos feitos pelos habitantes é sua proximidade para com o reator. Quanto mais perto o morador estiver da central, mais chance terá de ver sua solicitação atendida. Uma interpretação possível para esse critério é que o reator leva à naturalização do risco ao ampliar as vantagens de quem mora próximo à central. Além da proximidade com hospital e colégios, pode-se usufruir o atendimento para as iniciativas locais (idem, ibidem).

Com a eleição do presidente Luiz Inácio Lula da Silva (2003-2006), um ex-prefeito de Angra dos Reis, pertencente ao mesmo partido político do presidente eleito (PT), foi convidado para integrar a diretoria da ETN. Com a experiência de doze anos de envolvimento com a prefeitura da cidade (como secretário municipal, como vice-prefeito e, finalmente, como prefeito), o ex-prefeito assumiu a Direção de Administração e Finanças da ETN. Criou-se também uma assessoria voltada especialmente para as ações que visam compensar dos "impactos" as prefeituras de Angra dos Reis, Rio Claro e Paraty. Houve, então, a conformação, dentro da empresa, de um setor especificamente voltado para as ações compensatórias. Essa iniciativa parece decorrer de um uso específico da "política", que então passa a ser um mecanismo autorizado e privilegiado para a construção da relação da empresa com os moradores locais. 
Embora a empresa tenha feito um grande movimento com o propósito de se aproximar da população de Angra dos Reis, o PEE continuou sendo o tendão de Aquiles da ETN. Como ficou evidenciado em estudo anterior (Leite Lopes et alii, 2006), nas audiências para o licenciamento de Angra 2, o principal tema era a exequibilidade do Plano de Emergência, cuja credibilidade estava sempre ameaçada pelas quedas de barreira na estrada Rio-Santos, provocadas pelas chuvas. Contudo, como será visto a seguir, essa situação sofreu modificações perceptíveis nas audiências para o licenciamento prévio de Angra 3, nas quais o tema das "compensações" e do PEE dividiu espaço com o do "controle social". Essa mudança é de capital importância para a compreensão da natureza da participação dos cidadãos com relação ao risco nuclear, como se quer evidenciar aqui.

Diferentemente do que ocorre no Brasil, não há, na França, nenhuma forma de compensação material dos riscos advindos das centrais nucleoelétricas. Ainda que se considere que as grandes somas de impostos pagos pela central à municipalidade possam ter a mesma função, a prática compensatória explícita não é bem-vista, como conta um líder sindical, funcionário aposentado da companhia Eletricidade de França [Électricité de France - EDF], em uma entrevista:

A EDF disse: "Nós vamos fazer um traçado de um perímetro de certa área e quem estiver dentro dessa área terá uma conta de eletricidade menos cara". Mas o Conselho de Estado, que é um organismo nacional, disse: “Não. Isso vai contra o princípio da igualdade. Não há motivo para que uma pessoa que viva ao lado da central pague menos caro do que outra que viva a alguns quilômetros". Talvez eles tenham dito também: "Se fizermos isso para as pessoas que moram perto, talvez tenhamos de fazer para o trem que passa e, bom, a gente entra em uma engrenagem que não tem mais fim". Então, na França não há compensação financeira individual (sr. M.; tradução da autora).

Podemos entender a expressão "compensação financeira individual" como um mecanismo de criar distinções entre parcelas da população que estariam assim vitimadas, precisando de um ressarcimento. O que o entrevistado ironicamente observa também é que, sob um argumento tão louvável, pode existir outro, de ordem econômica. Se os vizinhos mais próximos da central são compensados rotineiramente, isso poderia dar margem a outros tipos de reivindicação de moradores mais distantes, mas passíveis de serem afetados. 
Na França, portanto, não existem mecanismos econômicos expressamente declarados de compensação do risco nuclear, uma vez que essa prática compensatória é entendida como de inspiração contrária à ideia de igualdade entre os cidadãos. Entretanto, além de medidas prévias que amenizem os efeitos sociais negativos provenientes da instalação de uma central, há grande vantagem financeira para as municipalidades que hospedam usinas, pois recebem impostos calculados sobre a produção energética das centrais nucleares. Mas são impostos que incidem sobre toda a atividade industrial, sem nenhuma correlação com uma possível compensação por impactos ambientais. Como as centrais são instaladas em cidades pequenas, estas aumentam sua arrecadação de forma que um município de 5 mil habitantes arrecade $o$ equivalente a um de 15 mil (Silva, 2007).

Até que se tenha uma lei que regulamente o pagamento de royalties, o debate sobre formas de compensação monetária devida pela empresa à municipalidade de Angra dos Reis vai estar em curso, bem como haverá suspeitas sobre a exequibilidade do PEE enquanto houver usinas nucleares. A construção da cidadania no Brasil, no entanto, torna possível o alargamento de temas trazidos à tona nesses espaços de aprendizado coletivo (Leite Lopes et alii, 2006:387).

Durante a quarta audiência pública para o licenciamento ambiental de Angra 3, membros da Sociedade Angrense de Proteção Ecológica (Sape) fizeram repetidas intervenções a fim de manifestar suspeitas sobre a exequibilidade do Plano de Emergência, mas igualmente argumentaram favoravelmente à existência de mecanismos de controle social das atividades da central, acompanhados pelo representante da Associação dos Quilombolas do Campinho da Independência. Contudo, o diretor da ETN, que compunha a mesa da audiência, argumentou pela inutilidade de tal acompanhamento, já que para tanto seria indispensável o conhecimento técnico do funcionamento do reator. A fala do diretor foi implicitamente contestada quando representantes da Procuradoria-Geral da República (PGR) e do Ministério Público (MP) deram importante apoio à demanda. Também o secretário de Meio Ambiente do Estado do Rio de Janeiro, presente na audiência, além de solicitar informações sobre o cumprimento das compensações estipuladas pelo MP por parte da Eletronuclear, manifestou-se favorável ao monitoramento, pela sociedade, do funcionamento das usinas. 
Como já se observou por ocasião da audiência pública para o licenciamento ambiental de Angra 2, ocorrida em 1999 (Leite Lopes et alii, 2006), o evento aqui em foco, de novembro de 2007, também extrapolou seu principal objetivo - a discussão do Relatório de Impacto Ambiental -, dando oportunidade para manifestações de diversas ordens por parte das associações presentes. Foi totalmente surpreendente, entretanto, ele ter sido igualmente palco para a exposição de pendências internas ao próprio universo nuclear, o que também aponta para a mudança que se quer evidenciar neste artigo. As audiências para a terceira unidade da central não abandonam as questões relativas às "compensações", cujo histórico foi sucintamente abordado anteriormente, e que ficaram em evidência nos procedimentos para o licenciamento da segunda unidade. Essas questões, porém, ampliaram o leque de problemas, incorporando discussões específicas à dimensão propriamente tecnológica do empreendimento.

Um físico da Comissão Nacional de Energia Nuclear (CNEN), sentado no espaço da audiência reservado aos funcionários da CNEN e da ETN, e, portanto, engrossando as fileiras daqueles que eram favoráveis ao empreendimento, usou do microfone para, em tom exaltado, criticar a superposição de tarefas assumidas pela CNEN: produzir e fiscalizar. Afirmou o físico que era inaceitável, do ponto de vista do bom funcionamento das atividades nucleares no Brasil, não haver completa independência institucional para a fiscalização. Acrescentou que os fiscais, como ele próprio, não tinham poder no exercício de seu trabalho e que irregularidades observadas na fiscalização ficavam, por isso, muitas vezes impunes. O que o funcionário - e representante sindical do setor - expunha então era uma suposta inadequação na forma de funcionamento da gestão institucional do risco. Assim, juntamente com a conformação mais nítida da demanda por meios de controle social, ganhavam terreno também as vozes descontentes do mundo nuclear.

Embora a inspiração institucional brasileira relativa à organização das atividades nucleares seja norte-americana ${ }^{9}$, nos Estados Unidos, as usinas nucleoelétricas são geridas por empresas privadas; da mesma forma, a fiscalização é realizada por empresas particulares e independentes entre si (Bourrier, 2004). No Brasil, o Estado produz, por meio da ETN, ao mesmo tempo que fiscaliza, por meio da CNEN. Portanto, enquanto a ETN é responsável pela produção energética, a fiscalização de toda a atividade e de todas as instalações nucleares em solo brasilei- 
ro é de responsabilidade da CNEN, autarquia criada em 1956 e ligada atualmente ao Ministério da Ciência e Tecnologia. A própria CNEN, contudo, além de órgão fiscalizador, é também proprietária da Indústria Nuclear Brasileira, localizada no município de Resende, que, entre outras funções, produz pastilhas de combustível para as usinas de Angra dos Reis. Essa superposição, no entanto, não é especificidade brasileira, ocorrendo também na França.

\section{O PAPEL DO EXPERTO}

Diversos autores discutem o papel e a importância do experto - também referido como técnico, cientista, especialista ou ainda perito - no processo de monitoramento de riscos contemporâneos decorrentes do processo de industrialização, bem como em disputas concernentes à chamada "questão ambiental". O assunto é extremamente rico porque seu exame relaciona necessariamente reflexões concernentes à construção da democracia e seus limites com questões de ordem epistemológica, aí incluídas as críticas à assunção da ciência como a única forma de produção de conhecimento verdadeiro sobre o mundo e seu modelo disciplinar. Entre as visões dos autores aqui referidos há tanto pontos de consenso quanto de divergências, algumas de grande e outras de menor importância, que mereceriam uma confrontação acurada em estudo voltado especialmente para tal exame. Assim, para mantermos o foco da análise, obras que seriam indispensáveis, no caso de uma discussão epistemológica mais abrangente (por exemplo, Bourdieu, 2000; 2007), permanecerão apenas como fonte de inspiração implícita. Neste artigo, será suficiente delinearmos pontos úteis para a compreensão do que seja o exercício da expertise.

Funtowicz e Ravetz $(1985 ; 1993)$ argumentam que há um esgotamento normal da ciência, considerando a acepção proposta por Thomas Kuhn. Os autores trabalham a ideia da possibilidade de outra forma de produção científica, a ciência pós-normal, que procuraria organizar a complementaridade entre as racionalidades científica e social, e aquela proposta pela propalada interdisciplinaridade, em voga a propósito de problemas ditos ambientais, cujo grau de complexidade requer a confluência de especialistas diversos. Também para Roqueplo (1992), a abordagem interdisciplinar não pode fundar sua objetividade sobre os métodos de validação da ciência clássica: a interdisciplinaridade deve sua autoridade às qualidades subjetivas daqueles que a elabo- 
ram, apontando também para a necessidade de novas bases para a produção científica.

Nesse mesmo sentido de crítica epistemológica, Beck (2001; 1994; 1995) e Latour $(1994 ; 1998 ; 2002 ; 2004)$ apresentam, em seus respectivos trabalhos, uma densa análise sobre a ciência e o papel que ela desempenha em uma sociedade democrática. Para Beck, a ciência é hoje uma das causas dos riscos industriais, além de ser o meio de defini-los e a fonte para solucioná-los (2001:341). Em virtude disso, ela abre novos mercados para si mesma. Beck afirma que a ciência lidava com um mundo "dado" e passou a lidar, reflexivamente, com seus próprios produtos, gerando o processo de autodesmistificação e a perda do monopólio da produção do conhecimento: assim, a ciência tornou-se cada vez mais necessária e cada vez mais insuficiente para produzir verdades. Explica ainda que essa mudança é produto da reflexividade do desenvolvimento tecnocientífico nas condições de uma "sociedade de risco" (ibidem:52; tradução da autora). Esse quadro caracteriza o que Beck denomina "cientização secundária, ou reflexiva".

Para o autor, as ciências abandonaram seu fundamento de lógica experimental e mantêm uma "união polígama com a economia, a política e a ética", vivendo uma espécie de concubinato permanente com elas (ibidem:53; tradução da autora); pensando tal poligamia como algo nocivo, acredita que o projeto iluminista de modernidade esteja inacabado. A cientização primária, que caracterizou a modernização da sociedade industrial até a primeira metade do século XX, extraía sua dinâmica da oposição, hoje questionada, entre profanos (leigos) e expertos. Beck conclui que os riscos, centro das atenções no período de "modernização reflexiva", trazem a incerteza, destroem o padrão de transformação intradisciplinar dos erros e dissolvem o modelo de cientização primária, com suas relações de poder harmoniosas, entre profissões, negócios, políticas e esfera pública. Beck clama então por um "segundo Iluminismo" (2003:203) que ultrapasse o primeiro, acrescentando ao projeto de uma ciência investigativa a dimensão reflexiva. Os riscos não seriam mais "externalidades" a serem alienadas do produto final da ciência: "Estou convencido de que as ciências precisam de um movimento e inclusive de uma divisão internos que absorvam mais a reflexividade da sociedade de risco na lógica da ação científica investigativa e técnica [...]. Para mim, essa seria uma peça importantíssima na construção do segundo Iluminismo" (ibidem:208; tradução da autora). 
Latour (2004) afirma que a denominada "crise ambiental", característica do que Beck chama de "sociedade de risco", é na verdade uma "crise de objetividade", já que a ciência perdeu a capacidade de produzir um único e incontestavelmente verdadeiro saber sobre a natureza, o que garantia para si a capacidade de explicação objetiva. Embora sua visão se aproxime da de Beck no que diz respeito ao papel central ocupado pela ciência em meio à propalada "crise", dele se distingue bastante quando argumenta sobre a impossibilidade de separar fatos de valores. Latour afirma que, apesar de a ciência supor tal separação, esta permanece restrita à ordem do discurso, jamais tendo sido realizada na prática (ver sobretudo Latour, 1994; 2004). A crítica que faz com relação à ecologia política justamente se fundamenta no fato de essa disciplina se sustentar sobre tal oposição, sendo, por isso, absolutamente incapaz de definir o bem comum para uma natureza desumanizada. No entanto, para Latour, ela faz algo melhor do que defender a natureza ao questionar as certezas concernentes ao bem comum, seja ele entendido como o dos homens (bem social), seja o das coisas (bem natural) (2004:37). Embora a ecologia política, afirmando falar em nome da natureza, mantenha viva a dicotomia que, segundo Latour, levou aos impasses hoje chamados "ecológicos", ela proporciona também o questionamento dessas compartimentações.

A crítica que Latour faz ao pensamento moderno (e à ciência) não pode ser confundida com aquela encontrada entre os construtivistas, pois afirma que, quanto mais se fala de uma "construção" da natureza, mais se deixa de lado o que se passa realmente na natureza abandonada à ciência e aos cientistas. Para o autor, a realidade não é redutível à sua representação, tampouco é a representação um filtro do real como se fossem entidades distintas: "Por que falar de coisas ou de suas representações simbólicas? [...] Crer que existem duas posições, o realismo e o idealismo, a natureza e a sociedade, é a fonte essencial do poder simbolizado pelo mito da Caverna ${ }^{10}$ e que a ecologia política deve hoje desmistificar [laïciser]" (ibidem:53; tradução da autora).

Para Latour, são os "coletivos" - conjuntos de humanos e não humanos, nos quais se delibera sobre um bem comum (ibidem:351) - que podem assegurar a superação das dicotomias modernas, incluindo a que separa ciência e representação ou realidade e simbolismo. Para o autor, não se trata de uma sociedade ameaçada, recorrendo, pela expertise, a uma natureza objetiva, mas de um coletivo em via de expansão: as propriedades dos seres humanos e não humanos sobre os quais esse con- 
junto deve deliberar não estão nunca irreversivelmente delimitadas; sempre podem ser expandidas. Afirma que, de fato, existe a realidade exterior, mas essa exterioridade não é jamais definitiva; apenas demonstra a existência de novos não humanos, antes não incluídos no trabalho do coletivo (ibidem:57). O coletivo assume a indissociabilidade entre fatos e valores. Conclui: "A natureza é objetiva, mas domesticada, e esse é um novo tipo de exterioridade. Os fatos não servem como prova, só como complicadores" (ibidem:55).

Se os fatos não servem como prova, então, como encarar o papel dos expertos?

Ao mesmo tempo que há uma crítica bastante difundida com relação à ciência como fonte única de produção de verdade, vários autores observam que ela se tornou a linguagem comum, constituindo a forma de conhecimento indispensável para a solução das questões consideradas "ambientais". É indiscutível, pois, a generalização do discurso científico pelos diversos setores da sociedade:

Revelemos, de início, um paradoxo. Enquanto durante os anos 1960 as ações coletivas organizadas em torno da questão da defesa do meio ambiente criticavam profundamente os saberes científicos e técnicos, além do modo de desenvolvimento social que eles propunham, as traduções dessas reivindicações em política pública desembocaram, ao contrário, em um recurso crescente aos expertos, engenheiros e técnicos, verdadeiros detentores dos reinos de um ecopoder também crescente (Lascoumes, 1994:8; tradução da autora).

Atualmente, todos aqueles que querem protestar contra as usinas nucleares, contra o aquecimento global ou ainda contra os organismos geneticamente modificados devem fazê-lo com base em argumentos científicos. Beck (2001) considera que os objetivos e os temas do movimento ambientalista foram gradualmente descolados de situações concretas, e demandas isoladas deram lugar a protestos gerais contra as condições e os pré-requisitos da industrialização. Os protestos passaram a ter como alvo ameaças invisíveis e intangíveis para o público leigo, ameaças que atingem os manifestantes e seus descendentes (Beck, ibidem:354).

Assim como Lascoumes (1994), Beck constata que muitas das ameaças ambientais requerem o apelo aos expertos porque inviabilizam qualquer possibilidade de percepção direta. Isso em nada diminui a impor- 
tância do protesto leigo, mas mostra sua dependência com relação a mediações científicas e suas medições. Outra constatação, também consensual para os autores aqui referidos, é que, muitas vezes, os cientistas, ao serem chamados para dar um desfecho a um debate, reiniciam outros, já que o grau de incerteza sobre os objetos científicos aumenta, dando margem a cisões entre os pontos de vista dos diferentes expertos. Em substituição ao monopólio de uma visão científica, ocorre então o apelo à sua pluralidade, propiciando a confrontação entre expertise e contraexpertise, isto é, mensurações e hipóteses de cientistas que podem estar em contradição entre si:

A incerteza não estabelece apenas problemas de decisão [...] ela é, com a multiplicação de controvérsias, um dos fatores que contribuem para o ingresso da ciência em meio ao debate social e para turvar as fronteiras entre cultura e natureza, apagando os limites cuidadosamente traçados entre medo e saber. Contribui para que o sonho positivista de uma sociedade governada pelo verdadeiro e pelo falso se confronte com a imagem de uma ciência tornada refém, instrumento de um jogo social em que se enfrentam poderes públicos, grupos de pressão e científicos, jogo no qual os expertos e a mídia ocupam doravante um lugar central (Theys e Kalaora, 1992:5; tradução da autora).

Corroborando as respectivas visões de Latour e Beck com relação à existência de uma ciência em crise ou questionada por seus efeitos reflexivos, Ravetz (1992), Theys e Kalaora (1992), Roqueplo (1992) e Ewald (1992), em textos voltados especificamente para a questão da expertise, evidenciam como o experto não pode mais ser visto como o detentor da verdade, sendo antes um dos diversos atores que participam dessa construção. Para esses autores, os representantes da ciência acabaram por exceder a tarefa original de produção do saber para exercer um poder despótico, típico da cientização primária (se quisermos usar os termos de Beck), sobre outras formas de conhecimento. O experto, portanto, não deve ser visto pelas partes envolvidas em uma querela como aquele que pode dar a última palavra: "[...] dar incondicionalmente fé à palavra do experto, em nome de sua competência, é assumir risco também enorme de se remeter a um tipo de despotismo esclarecido que, dessa vez, se estende a todo o planeta" (Theys e Kalaora, 1992:5-6; tradução da autora).

O recurso à expertise e à contraexpertise pode levar a um real confronto entre as informações divulgadas por indústrias, tais como uma central nuclear, e as que podem ser obtidas por outras fontes, como laborató- 
rios considerados "independentes". É verdade que a divergência pode decorrer da má-fé - uma indústria interessada em manter seus lucros nega os efeitos danosos da poluição que provoca -, mas não é isso que está em discussão. Frequentemente as visões díspares decorrem do grande grau de incerteza com que lidam hoje os cientistas. Nesse sentido, Nelkin e Pollak (1981) afirmam com ironia que sempre há cientistas para falar a favor e outros para falar contra. Acrescente-se a isso o fato de haver, além da científica, outras formas de racionalidades em jogo que devem ser levadas em consideração para a tomada de uma decisão política, como bem observam Theys e Kalaora:

A partir do momento em que a comunidade científica aceitar como não absurda a ideia de que a opinião geral pode ter razões que não são necessariamente as mesmas que as suas - como o fato de que, na Suécia, três quartos da população foram desfavoráveis ao nuclear, enquanto três quartos das instituições científicas foram favoráveis -, um diálogo entre culturas (a do visível e a do invisível) poderá ser estabelecido e servir de base para uma verdadeira democracia esclarecida (1992:40; tradução da autora).

Há portanto muitas divergências entre cientistas e seus pares, entre leigos entre si e entre cientistas e leigos para serem conciliadas. Para tanto, surgem diversas alternativas de reuniões democráticas feitas justamente com o propósito de concertação, como são as audiências públicas. Callon, Lascoumes e Barthe, refletindo sobre a realidade francesa, propõem a construção de uma "democracia técnica" (2001:326), entendendo que profanos e cientistas podem contribuir para o avanço da ciência discutindo, de forma ampla, problemas em que a incerteza é grande em espaços que denominaram "fóruns híbridos", base da mencionada "democracia técnica", em que há a tradução do jargão científico para uma linguagem acessível ao leigo. Callon considera, com outros autores (Callon e Rip, 1998; Callon, Lascoumes e Barthe, 2001), que há uma tendência crescente de formação desses espaços assim definidos

fóruns porque são espaços abertos, onde grupos podem se mobilizar para debater escolhas técnicas que comprometem o coletivo. Híbridos porque os grupos comprometidos e seus porta-vozes são heterogêneos; neles se aglutinam expertos, homens políticos, técnicos e profanos, que se consideram concernidos pelo problema. Híbridos também porque os problemas abordados e as questões levantadas se inscrevem em registros variados que vão da ética à economia, passando pela fisiologia, 
física atômica e eletromagnetismo (Callon, Lascoumes e Barthe, 2001:36; tradução da autora).

Os fóruns híbridos são então dispositivos de elucidação e, para seu funcionamento, devem pressupor que a verdade nunca está apenas em um dos lados. Por esse mesmo motivo, pelo apreço ao exercício da pluralidade, Callon, Lascoumes e Barthe observam que os atores comprometidos em uma controvérsia sociotécnica não podem aceitar o monopólio dos expertos (ibidem:60). Para Callon e Rip (1998), ainda é preferível falar de expertise a falar de experto, pois a expertise é o produto do trabalho de um fórum híbrido no qual são confrontadas as visões de profanos e expertos, seus métodos e instrumentos de trabalho:

A expertise envolve não somente humanos (os atores do fórum híbrido), mas também os artefatos técnicos (sistemas peritos, instrumentos de medida...) nos quais se encontram incorporados e estabilizados procedimentos legitimados de análise, conhecimentos plausíveis, verdadeiros protocolos. A expertise é o conjunto do dispositivo sociotécnico que cria condições para a produção do acordo (ibidem:181; tradução da autora).

Uma das principais preocupações de Callon e Rip é mostrar como os profanos podem incorporar a linguagem técnica e ampliar o conhecimento científico em "laboratórios" heterodoxos, montados informalmente por cidadãos envolvidos em conflitos ambientais, no sentido amplo do termo. Os leigos podem adquirir bom conhecimento sobre o assunto e somar seus esforços aos dos pesquisadores.

Para os autores citados nesta seção, é consenso que a participação democrática não pode ser conquistada se a ciência anular outras formas de racionalidade. As acusações de ignorância contra os leigos são argumentos de autoridade da parte de empreendedores e cientistas na disputa política por seus interesses. Isso motiva reflexões como as de Beck, Funtowicz, Ravetz, Callon e Lascoumes, em sua tentativa de idealizarem formas de construção da ciência em que outras racionalidades serviriam de complemento.

Frequentemente, a oposição ao projeto de implementação e de aumento da central nuclear brasileira é vista por seus empreendedores como fruto de "desconhecimento" e de "ignorância" (Silva, 1999a). Contudo, a audiência pública ocorrida em 26 de novembro de 2007, para o licenciamento prévio da usina nuclear Angra 3, não foi tão marcante por 
esse tipo de postura por parte dos técnicos, revelando uma alteração no comportamento dos representantes da empresa ao lidar com os oponentes do projeto. No evento, os cientistas/engenheiros da central nuclear puderam ziguezaguear com desenvoltura entre os "fatos" e "valores", somando às argumentações tecnicamente embasadas outras, de ordem social, tais como o compromisso de oferecerem novas vagas de emprego aos moradores locais. Os profanos, ao contrário, necessitam, para seu zigue-zague, de um experto que faça a tradução, como pleitearam representantes da Associação dos Quilombolas do Campinho da Independência, de Paraty, da Sociedade Angrense de Proteção Ambiental (Sape) ${ }^{11}$, da PGR, do MP e também o secretário de Estado de Meio Ambiente (RJ). A generalização da percepção segundo a qual a mediação de um experto é fundamental para o "controle social" das atividades industriais consideradas perigosas não se dá apenas entre os teóricos preocupados com o assunto, sendo compartilhada também entre os leigos.

O papel desse experto seria, seguindo a proposição de Ewald (1992), menos o de fornecer soluções do que o de propor termos que tornem possível a negociação sobre os valores que o tema do meio ambiente institui. Ele seria peça fundamental no monitoramento das atividades da central, confirmando os termos de seus relatórios diários e dando a chance de a população se posicionar a respeito de eventuais disfunções. Ou, como querem Callon e Rip, "os expertos contribuem, por meio de sua atividade, para o estabelecimento de um compromisso: eles são verdadeiros mediadores (1998:167; tradução da autora).

\section{ASPECTOS DA DEMOCRATIZAÇÃO DAS ATIVIDADES NUCLEARES CIVIS}

\section{A Presença do Estado}

Na França, as centrais elétricas nucleares pertencem à empresa estatal Eletricidade de França (EDF), que, a despeito de manifestações contrárias promovidas por sindicatos e partidos de esquerda, se abriu ao capital privado a partir de 2004. Com função análoga à da Comissão Nacional de Energia Nuclear (CNEN) no Brasil, a Autoridade de Segurança Nuclear (ASN), que também é uma instituição da administração pública francesa, tem por atividade a fiscalização das condições de trabalho dos funcionários das centrais e do funcionamento dos reatores. Lá, esse tipo de "endogamia" vem sendo muito criticado, até mesmo por cientistas adeptos do programa nuclear francês. 
Então, se há alguma semelhança entre os programas nucleares brasileiro e francês ${ }^{12}$, é que, em ambos os casos, o Estado acumula os papéis de empresário e fiscalizador. Tal superposição de tarefas sempre foi criticada pelos Estados Unidos, que condenam essa prática desde os anos 1950, quando sua indústria nucleoelétrica passou para a iniciativa privada, logo após o funcionamento dos primeiros reatores. Lá, então, sendo a produção e a fiscalização feitas por companhias particulares e independentes, espera-se que haja, a princípio, uma maior objetividade nos procedimentos fiscalizadores.

Na década de 1970, em países da Europa, essa superposição já era um motivo de questionamento dos programas nucleares por parte dos cidadãos, como mostram Nelkin e Pollak (1981). Os autores narram que, na Alemanha, uma professora evidenciou a existência de relações informais entre uma usina nuclear que estava sendo planejada e as autoridades responsáveis pelo licenciamento. Ela iniciou um movimento contra o projeto alegando conluio entre fábrica e autoridades licenciadoras; após cinco anos de processo, conseguiu interromper a construção da central naquela localidade (ibidem:60).

A superposição encontrada em países europeus, nos quais o Estado concentra funções de construção, licenciamento e fiscalização, deve-se a razões econômicas. Também o caráter "estratégico" das atividades nucleares, em virtude de o urânio, depois de usado para fins de produção elétrica nas centrais termonucleares, poder servir para a fabricação de armas, é um fator que contraindica, para muitos países, a privatização do setor. Nelkin e Pollak observam que, na Europa, governos e indústria são necessariamente parceiros no custoso empreendimento que é a energia nuclear. Afirmam, além disso, que o tamanho do custo da empresa nuclear tende a reduzir a autonomia do governo na área política, limitando sua disponibilidade para atender a solicitações da população, porque o investimento inicial é sempre tão volumoso que passa a justificar os investimentos subsequentes, na tentativa de se amortecer os gastos anteriores (ibidem:188).

A política nuclear na França, na Alemanha e na Suécia é vista, por Nelkin e Pollak, como um setor em que a teoria do capitalismo monopolista de Estado é aplicada. Em 1974, quando o aumento do preço do petróleo foi uma pressão para se criar fontes alternativas de produção de energia, esses três países se tornaram rapidamente promotores de energia nuclear nacional e internacionalmente. Também em 1974, Bél- 
gica, Holanda e Itália fizeram um consórcio (apenas Áustria, Dinamarca e Noruega renunciaram à tecnologia nuclear). Nesses casos, a falta de comprometimento com uma indústria nuclear nacional e laços econômicos relativamente limitados entre governo e usinas nucleares permitiram aos governos manter maior independência na regulação e maior possibilidade de responder aos apelos da população.

Se, como analisam Nelkin e Pollak, nos países industrializados, o investimento em uma usina nuclear é tão elevado que cria constrangimentos para a democratização do setor, esse quadro em outros países não é diferente, e isso só reforça a importância da conquista de fórmulas participativas que levem ao controle social pelo acesso à contraexpertise. A constatação de que o envolvimento estatal com a produção nuclear restringe a possibilidade de concessões no que concerne às demandas sociais não significa, em absoluto, que a privatização das centrais nucleares em um país como o Brasil garantiria um maior controle social das atividades. Ao contrário, o Estado poderia estar menos comprometido financeiramente, porém mais incapaz de intervenção favorável a tais reivindicações.

\section{A Legitimação do Risco}

Como se vê entre os moradores das cidades francesas que hospedam usinas, também em Angra dos Reis a maioria dos habitantes não está interessada no monitoramento do risco. Há, entretanto, uma parcela da população, numericamente pouco expressiva, que se manifesta organizadamente e se preocupa com a questão do risco nuclear. Trata-se dos cidadãos que são contrários à central, pois veem em tal risco algo a ser evitado. São autodenominados "ambientalistas" e se empenham para conseguir provas da empresa de que tudo vai bem com os reatores. É plausível que cidadãos favoráveis ao empreendimento também queiram para si o direito de ter acesso às informações sobre o que ocorre na central, mas essa preocupação acaba sendo associada pelos empresários aos "antinucleares".

A desconfiança nutrida pelas associações (ambientais e outras) com relação às informações dadas pelos técnicos da central decorre, pelo menos parcialmente, da postura dos engenheiros da Eletronuclear (ETN). Durante anos, essa postura foi a de não se submeter à prova nem ao diálogo, não se aproximando da população circunvizinha. Em todo o mundo, a atividade industrial nuclear evoca para a grande parte das 
pessoas a ideia da existência de um grande perigo (Chiva, 1970; Zonabend, 1989). No entanto, o medo e a desconfiança não são necessariamente manifestados ou canalizados para ações contestatórias ou de vigilância.

Recentemente, na França, o confronto entre as visões dos engenheiros/cientistas das centrais nucleares e aqueles denominados "independentes", por não pertencerem às instituições oficiais que conformam o programa nuclear francês, vem sendo considerado um passo importante para o monitoramento dos riscos advindos dos reatores nucleares. Lá foram criadas as Comissões Locais de Informação (CLIs), formadas com o objetivo principal de acompanhar o funcionamento das centrais nucleares francesas, constituídas de representantes da população, da empresa nuclear e de membros do órgão fiscalizador. As CLIs se reúnem uma ou duas vezes por ano. Ao longo das reuniões, engenheiros fazem relatório de suas atividades nas centrais, assim como os técnicos da instituição fiscalizadora (Silva, 2007). Das trinta CLIs existentes, cerca de cinco são consideradas "atuantes", isto é, buscam entender e debater os relatórios apresentados; as outras têm um funcionamento considerado "formal". São as comissões "mais ativas" que vêm tornando usual a confrontação entre expertise e contraexpertise ${ }^{13}$.

No Brasil, as audiências, que são espaços de natureza bastante distinta das CLIs, são utilizadas sobretudo para a discussão das compensações e dos ressarcimentos que a empresa deve à municipalidade. Nelas, muitas associações de moradores vêm com faixas manifestar seu apoio à ETN, com a expectativa de que a companhia traga "benfeitorias" para seu bairro. Essa troca é explicitada por alguns representantes; outros negam que estejam ali a troco de benefícios, afirmando que sua presença é movida por um ideal maior, como o "progresso" que a usina representa. O surgimento de novo tipo de reivindicação - controle social - referido propriamente à questão do risco aponta para uma mudança na qualidade da participação que ali é construída.

Diferentemente do que ocorre em um país periférico como o Brasil, na França, o não reconhecimento de um "passivo" pode ser explicado pelo fato de que, em um país central, "nuclearizado", a função social de produção de riquezas cumprida pela industrialização se legitima com relação a um bem comum. Os riscos seriam o mal necessário (Beck, 2001), e, dessa forma, a participação deve ser pragmaticamente voltada sobretudo para a vigilância do cumprimento das normas de segu- 
rança pela empresa. No Brasil, como a função social de produção de riqueza para o bem comum, usufruído, portanto, por todos, não fica clara, a participação dos cidadãos gira primordialmente objetivando um "arranjo" (Boltanski e Thévenot, 1991:163) em que alguma vantagem financeira venha a beneficiar a população já ameaçada pelo risco. No entanto, o fato de, na França, a participação intentar, notadamente, o acesso às informações sobre o que ocorre no interior das usinas não significa, como já foi dito, que lá a instalação de uma usina não traga vantagens financeiras à municipalidade que a hospeda, mas apenas que não há dispositivo legal ou institucional que assegure o ressarcimento de um "passivo" a ser resgatado.

A adoção desse tipo de espaço para a participação só pode ser explicada por uma multiplicidade de fatores - históricos, econômicos, sociais e culturais. Esses mesmos fatores constituem diferenças notáveis entre países como o Brasil e a França; por exemplo, os efeitos legitimadores provenientes de décadas de um desenvolvimento voltado para o bem-estar social. Se é em países industrializados que encontramos melhores condições para o exercício da cidadania e, consequentemente, a possibilidade de presença de movimentos sociais organizados, é também neles que os riscos encontraram até então sua forma mais bem-acabada de legitimação moralmente justificada: produção de riqueza e sua distribuição nem tão desigual. Esse raciocínio endossa as colocações de Beck, segundo as quais entre o risco e a fome preferimos o risco (2001:72), o que é moralmente ruim porque na verdade não se trata de opção.

\section{O Recurso à Expertise}

Na França, a prática do bénévolat, isto é, do trabalho oferecido voluntária e gratuitamente, é muito difundida graças, sobretudo, ao grande número de pessoas aposentadas e com bom nível de escolaridade dispostas a continuar em atividade. Assim, cientistas aposentados passam a contribuir para o debate a propósito do risco nuclear participando de comissões como as trinta CLIs existentes e de sua associação nacional, denominada Associação Nacional das CLIs (Ancli). No seio dessas comissões, o acesso às informações sobre o que se passa no interior das centrais pôde ser transformado em rotina. Faz parte das atividades dessas associações a "formação" de seus membros profanos, que são então iniciados no tipo de conhecimento específico requerido para a monitoração dos riscos nucleares (Silva, 2007). Esse tipo de con- 
certação exige um grande esforço político das partes envolvidas, pois, naquele país, o assunto "nuclear" é considerado "sensível"14 e a metáfora de uma "guerra civil" (cf. Touraine et alii, 1980, e Nelkin e Pollak, 1981) descreve frequentemente os embates entre os favoráveis à utilização dessa alternativa energética e os que são contra, também chamados "anti".

A existência de um bom número de expertos que levem à frente controvérsias está correlacionada às condições de escolarização e ao nível de escolaridade de uma população. O tamanho do parque nuclear também deve ser levado em conta, pois depende da formação de profissionais especializados e propicia a ampliação das instituições de ensino e de pesquisa nessa área específica. Talvez ele possa igualmente explicar, muito embora parcialmente, a criação de canais institucionalizados de participação para monitoramento. A importância econômica do parque nuclear francês, instalado inicialmente pelo presidente Georges Pompidou, com todas as implicações sociais e políticas que essa grande presença traz à França, foi, indiscutivelmente, um relevante fator considerado para a criação pelo governo Mitterrand das CLIs francesas. O número de usinas e o consequente volume de dejetos gerados torna inevitável, em um país democrático, a criação de algum tipo de estratégia para os promotores do "mundo nuclear" responderem às inquietações da população.

No Brasil, a falta de profissionais especializados certamente impõe um problema à efetivação do pleiteado controle social. Com a intenção de viabilizar o monitoramento, o secretário de Meio Ambiente do Estado, na audiência de novembro de 2007, sugeriu que a empresa deixasse disponível para a população das proximidades da usina instrumentos de mensuração, a fim de que os interessados pudessem ter autonomia para verificações que certificassem a ausência de substâncias prejudiciais ao ambiente. A utilização desses instrumentos, porém, bem como o que medir, não é tarefa simples.

Assim, a figura do experto independente (na França chamado para o exercício da contraexpertise) parece indispensável para o efetivo controle social das atividades industriais e poluentes. Como já comentado, o apoio de atores institucional e politicamente importantes, como aquele trazido pela PGR e pelo MP à implementação de mecanismos de controle social, fazendo eco à reivindicação de associações como a Sape e a dos Quilombolas do Campinho da Independência, de Paraty, é 
uma novidade nas audiências públicas de 2007, relacionadas à Angra 3 , inexistente naquelas organizadas para o licenciamento de Angra 2 no fim dos anos 1990.

\section{A Vontade de Transparência}

Tanto na França quanto no Brasil as respostas dos promotores da energia nuclear à dupla acusação de que a indústria nuclear é uma das mais perigosas e secretas permeiam três pontos: (1) ressaltar o perigo existente em outras formas de atividades, produtivas ou de outra ordem, advogando uma compreensão estocástica do mundo; (2) diminuir a importância dos eventos ocorridos nas instalações nucleares. Assim, o vazamento de alguma substância nociva é sempre um "pequeno vazamento", e os incidentes são sempre "incidentes sem nenhuma importância". Quando o reconhecimento da gravidade de um acidente é inevitável, há a comparação com uma catástrofe que aconteceu em outro lugar, em outro canto do mundo, onde as medidas de segurança são precárias ou a tecnologia é menos confiável; e (3) reconhecer, ao menos no plano do discurso, a necessidade de democratização do setor.

A "participação da população" se tornou exigência legal ${ }^{15}$ e ambição política dos agentes envolvidos em contendas consideradas "ambientais". O incremento das "fórmulas participativas" que passam cada vez mais a constituir formas de administração e de sociabilidade política pode ser entendido basicamente sob a ótica de duas vertentes. A primeira, como uma demanda da própria sociedade organizada e fruto do conflito, inerente à democracia, entre representação e representatividade. A segunda, como um mecanismo que vem facilitar o propalado encolhimento do Estado. Essas interpretações de grande alcance são indispensáveis para a articulação do trabalho sobre uma situação específica com uma realidade mais ampla; porém, são inspirações que só explicam parcialmente os processos locais. Por isso, o estudo do fenômeno da "participação" por cientistas sociais tem consistido em sua qualificação, como atestam os trabalhos de Ashforth (1980), Defrance (1988), Beynon (1999) e Leite Lopes (Leite Lopes, 2004; Leite Lopes et alii, 2006), que versam sobre casos específicos de audiências públicas.

Ashforth (1980) considera que as audiências são um espaço em que o poder do Estado (no caso, a empresa ETN) é reafirmado com a submissão dos grupos contrários ao empreendimento. Diferentemente de Ashforth, Beynon (1999) admite que, em tais contextos, pode ser esta- 
belecida a possibilidade de uma negociação entre as partes, abrindo chance para conquistas por segmentos da população que recebem os empreendimentos. Para Defrance (1988), há uma oscilação entre duas situações: em alguns momentos, trata-se de um canal de comunicação entre as partes reunidas; em outros, surge a possibilidade de negociação. Se entendermos o espaço da audiência pública como um espaço de negociação, a observação de Lascoumes (1994) é também especialmente pertinente:

A negociação é uma prática social muito sedutora para não ter sombras, muito valorizada hoje para não dissimular os novos jogos de dominação. É necessário dizer claramente que nada é mais alienante que uma negociação desigual, nada é mais enganoso que uma negociação improvisada, nada é mais ilusório que um pretenso ajustamento de interesses desprovido de todo o contexto que o estrutura e lhe fixa os limites (ibidem:287; tradução da autora).

O caráter das audiências públicas que são referência para a presente análise não pode ser definido como um processo de negociação sobre o que está em pauta, mas sim de negociações secundárias e possíveis que substituem a principal, já definida. Por exemplo, na audiência para o licenciamento prévio de Angra 3, uma representante do MP insistia na inconstitucionalidade de se decidir pela licença sem que a discussão fosse ao Congresso. A ETN defendeu que não haveria necessidade de aprovação pelo Congresso Nacional, pois essa unidade, fazendo parte do acordo firmado com a Alemanha em 1975, já teria tido sua aprovação antes da Constituição de 1988, na qual se baseava a procuradora. De qualquer modo, essa discussão não polarizou a reunião. A maior parte do tempo do evento, que durou seis horas, foi dedicada a pronunciamentos de entidades locais favoráveis à ampliação do sítio nuclear e que solicitavam providências, as mais diversas, relacionadas a melhorias urbanas para Paraty e Angra dos Reis, e aproveitamento de mão de obra local. As entidades oponentes também fizeram seu papel questionando a confiabilidade do Plano de Emergência e reclamando por controle social. No fim da audiência, a procuradora disse: "Não se preocupem, Angra 3 vai sair de qualquer maneira; isso já está definido pelo governo. O que estou colocando é que, se não for aprovada pelo Congresso, será um processo inconstitucional"16.

Em conversas informais com alguns funcionários da ETN, entendi que os representantes do MP, no exercício da defesa dos direitos difusos, são percebidos como críticos do programa nuclear brasileiro. Estender 
o debate e levá-lo ao Congresso, com risco de uma desaprovação por parte dos congressistas, é algo visto como oposição, e não como uma démarche democrática ou constitucional. Por outro lado, os opositores acreditam que o aumento do sítio é visivelmente um mau negócio em termos ambientais, e a lógica dos engenheiros, que muitas vezes ainda funciona em termos de "cientização primária", é confundida com má-fé.

Como conciliar, em um mesmo coletivo ou em um mesmo fórum, interesses tão discrepantes? Um bordão usado pela ETN em audiência anterior, para Angra 2 (Leite Lopes et alii, 2006), ilustra a expectativa dessas reuniões. "Tudo às claras" era a frase que sintetizava a função social da empresa (produção elétrica) e sua disposição de abandonar a velha prática do segredo, entidade intrínseca ao "mundo nuclear". Para Theys e Kalaora (1992), as relações entre saber e democracia são

atualmente inteiramente sobredeterminadas pelo fato de que nós vivemos em uma sociedade de comunicação generalizada e que atribui um lugar central - e quase mágico - a um "mito" maior: o da transparência. Inseparável de certa concepção de participação pública na decisão, a noção de transparência recobre de fato várias ordens de realidade diferentes. Em um primeiro sentido, ela é quase extensão do papel da mídia - e em todo o caso a redução ao mínimo do segredo. Em uma segunda acepção, ela evoca antes uma democracia aberta: a vontade de fundar relações sociais sobre um tratamento adulto da opinião, ou seja, a verdade e a responsabilidade. Em um terceiro plano, ela remete mais profundamente à capacidade que possuem ou não as sociedades de se autoconhecerem e autogovernarem, com toda a lucidez, a partir do que sabem de si e da evolução do mundo. É o ideal iluminista de autotransparência (ibidem:35-36; tradução da autora).

Entretanto, como concluem os mesmos autores, a proliferação de informação não cria necessariamente transparência; ao contrário, produz um efeito de turvamento (ibidem:37-38). Admitem, contudo, que a transparência é uma necessidade social a ser construída de maneira voluntarista, ou seja, como uma nova forma de "contrato social" (ibidem:39). Esse efeito de turvamento pode ser explicado pela impossibilidade de separar fatos de valores, como bem afirma Latour em suas obras. Como também explicam Theys e Kalaora, o reconhecimento da impossibilidade de transparência não significa que a informação seja supérflua; ao contrário, ela continua sendo fundamental para a formação de pactos e compromissos. 
Tomando o caso das atividades nucleares para exemplificar o que está sendo dito, posso mencionar a prática das mensurações. As usinas nucleares, para seu funcionamento, devem obedecer a acordos internacionais que estipulam as quantidades das diversas substâncias a serem lançadas no exterior da fábrica (atmosfera, rios ou mares). As usinas empreendem então constantes medições para verificar se há algum vazamento indevido cujos resultados, embora não sejam acessíveis à compreensão leiga, podem ser debatidos por intermédio de um perito. Mesmo levando em conta a multiplicidade de métodos de medição, a transparência não é, nesse caso específico, algo inatingível. Seu questionamento começa quando o funcionamento normal da fábrica e as medições, até então aceitas, perdem, por algum motivo, sua legitimidade. Assim, o problema da expertise ultrapassa a questão da pura informação porque inclui uma discussão sobre o que é aceitável, turvando a transparência dos laudos com interesses e valores díspares.

Já foi mencionado que Latour (2004) associa esse processo de composição de referências empíricas (os chamados fatos) e de valores com a formação de um coletivo. Esse coletivo seria produto, por um lado, do reconhecimento de que a realidade objetiva nunca é só objetiva, porque ela é também representada e narrada; por outro, da concomitante superação de dicotomias modernas, tais como natureza / cultura. O autor afirma: "A democracia só pode se pensar com a condição de poder atravessar livremente a fronteira entre ciência e política" (ibidem:107; tradução da autora).

Enquanto essa revolução epistemológica não se generaliza nas práticas política e científica, ou enquanto o segundo Iluminismo de Beck não encontra, nos vários pontos do planeta, possibilidade de efetivação, as associações favoráveis ou desfavoráveis à instalação de Angra 3 dão mais um passo em direção à construção da cidadania e da democracia brasileiras, clamando por condições de monitoramento independente do funcionamento da CNAAA.

\section{CONSIDERAÇÕES FINAIS}

Discutiu-se, neste artigo, a especificidade da "participação" de cidadãos em contextos de risco nuclear, evidenciando-se que essa participação depende da mediação de um profissional que se disponha a fazer a tradução do jargão científico característico dos relatórios técnicos e/ou faça seu próprio relatório, a título de contraexpertise; do contrá- 
rio, os leigos não poderão legitimar seus argumentos cientificamente. O recurso à linguagem e à racionalidade científicas é a condição para que se diagnostique um mal e se oponha a ele. A supremacia da ciência como a produtora da verdade por excelência se mantém, embora não mais como um monopólio.

Se antes as controvérsias entre técnicos e leigos eram convertidas rapidamente em uma luta entre os detentores do conhecimento versus o desconhecimento, atualmente isso muda em dois aspectos: 1) os leigos se apropriam cada vez mais do saber científico para fazerem valer suas demandas; 2) os próprios cientistas divergem entre si em virtude do grau de incerteza que hoje permeia o exercício de estabilização do conhecimento, ou "fechamento de caixas-pretas", nos termos de Latour (1998).

A centralidade da figura do perito ou, dito de outra forma, a importância crescente da pluralidade de expertise pôde ser atestada em uma amplificação do discurso de associações por representantes de instituições de caráter estatal - MP, PGR e Secretaria de Estado do Ambiente do Rio de Janeiro (SEA/RJ) - em direção à exigência de controle social sobre as atividades nucleares da CNAAA. Assim, a almejada "participação da população", fundamental para o exercício da democracia no Brasil, muda de qualidade na medida em que não se restringe à expressão dos descontentes em um plano estritamente das reivindicações compensatórias, indispensáveis, mas facilmente manipuladas a favor de uma legitimação da empresa.

Por mais que as relações de dominação possam constranger os resultados das audiências em que se discute a ampliação da central nuclear de Angra dos Reis, tornando perdida a contenda entre os adeptos do nuclear e os segmentos da população contrários à presença desse tipo de indústria na matriz energética brasileira, e por mais que haja argumentos científicos favoráveis a cada um dos lados, a complexificação do debate dá chance - com a entrada em cena da demanda por monitoramento social - para que as assimetrias sejam revistas, abrindo espaço para mudanças. Assim, o objetivo neste artigo foi inscrever essa pequena e importante mudança como uma peça na construção da relativamente jovem democracia brasileira.

(Recebido para publicação em janeiro de 2008) (Versão definitiva em maio de 2009) 


\section{Gláucia Silva}

\section{NOTAS}

1. A aprovação do local para a construção da usina nuclear Angra 3, concedida originalmente em 1980, foi referendada pela Resolução da Comissão Nacional de Energia Nuclear (CNEN) nํำ 11, de 19 de setembro de 2002. O Conselho Nacional de Política Energética (CNPE), ligado à Secretaria de Assuntos Estratégicos, aprovou, em 25 de junho de 2007, a retomada da construção da usina Angra 3, que deve começar a funcionar em 2014.

2. A primeira audiência ocorreu na cidade de Angra dos Reis (19 de junho de 2007); a segunda, em Paraty (20 de junho de 2007); a terceira, em Rio Claro (21 de junho de 2007). Houve ainda cerca de dezessete pequenas reuniões intermediárias que prepararam as três maiores. Consultei também, para este estudo, a documentação relativa às audiências nas quais não estive presente, disponibilizada ao público tanto pelo Ibama quanto pela empresa Eletronuclear (ETN).

3. Tive a oportunidade de visitar o município para pesquisas consecutivas. Inicialmente, entre 1992 e 1994, realizei um estudo para minha tese, junto com os trabalhadores da usina nuclear Angra 1 e seus familiares, abordando a questão da construção social do risco tecnológico (Silva, 1999a; 1999b). Em um segundo momento, já integrando a equipe de pesquisa coordenada por José Sérgio Leite Lopes (Universidade Federal do Rio de Janeiro - UFRJ / Museu Nacional - MN), voltei a Angra dos Reis preocupada com a questão da "participação da população", frequentando reuniões da associação de moradores e verificando a implementação do plano diretor (que havia sido elaborado entre 1990 e 1992) sob a efervescência de prefeituras do PT, ciosas da "participação popular" (Leite Lopes et alii, 2000; 2006; Leite Lopes, 2004).

4. Outros antropólogos também desenvolvem pesquisas sobre temas correlatos no local, tais como Prado $(2002 ; 2003)$ e Bezerra $(1995 ; 1999)$.

5. Empresa brasileira fundada em 1975 para projetar e construir usinas nucleares.

6. Essa e outras entrevistas com funcionários da ETN foram feitas ao longo do projeto intitulado Degradação Ambiental, Poluição e Risco Tecnológico: Um Estudo de Caso no Litoral de Angra dos Reis/RJ, que coordenei entre 2000 e 2004.

7. Como já foi dito na introdução, em 1986, o Conama instituiu uma política nacional de avaliação de impactos ambientais, exigindo estudos de impacto ambiental e audiências públicas para o licenciamento de atividades poluidoras. Além disso, em 1985, já havia sido criada a lei da ação civil pública, que é um instrumento para que a sociedade civil busque ressarcimento dos danos causados ao meio ambiente, entre outros. Ela assegura o direito de associações privadas, organizações não governamentais e Ministério Público (MP) agirem, na justiça, contra os poluidores.

8. O instrumento da compensação está especificamente tratado no art. 36 da Lei $n \underline{0}$ 9.985, de 18 de julho de 2000, que institui o Sistema Nacional de Unidades de Conservação, regulamentado pelo Decreto n으 4.340, de 22 de agosto 2002, alterado pelo Decreto $\mathrm{n}$ o 5.566/2005. É um mecanismo financeiro de compensação pelos efeitos de impactos não mitigáveis ocorridos quando da implementação de empreendimentos e identificados no processo de licenciamento ambiental. Esses recursos são destinados às Unidades de Conservação para a consolidação do Sistema Nacional de Unidades de Conservação (SNUC). 
9. Isso é explicado também pelos múltiplos acordos estabelecidos entre Brasil e Estados Unidos, na área nuclear, desde a década de 1940, e que incluíram, na década de 1960, a compra da primeira usina nuclear que funcionaria em solo brasileiro, Angra 1, da empresa norte-americana Westinghouse (Silva, 1999a).

10. Refere-se à alegoria de Platão em A República.

11. A Sape reúne militantes que ainda hoje continuam um movimento, "Hiroshima nunca mais", iniciado no primeiro ano da década de 1980.

12. A França exemplifica o que se denomina "país nuclearizado": além das dezenove centrais nucleoelétricas, lá se encontram nove centros do Commissariat à l'Energie Atomique (CEA), dois centros de estocagem de rejeitos radiativos, um centro de tratamento, algumas instalações de fabricação de combustível e de condicionamento de combustível, um laboratório de pesquisa sobre estocagem subterrânea, o complexo de Marcoule e, finalmente, a base secreta de Valduc. O fato de o Brasil ter até então dois reatores comerciais em funcionamento e a França possuir 58 já evidencia que a produção de eletricidade a partir de urânio tem pesos muito distintos dentro desses países. Estão aqui, portanto, sendo contrastados aspectos de dois programas nucleares cujas magnitudes são bastante diferentes.

13. As mensurações que constam dos relatórios dos funcionários das centrais nucleares são comparadas, pelos cidadãos, com aquelas fornecidas por cientistas e técnicos não vinculados à central nuclear. Em caso de disparidade de resultados, é no interior das CLIs que o debate entre representantes da população, da empresa e fiscais acontece.

14. A reação de alguns franceses ao ouvir o teor de meu estudo é útil para avaliarmos quão polêmico é o assunto: "você não tem medo de acabar numa caixa de concreto dentro do Sena?", "você não tem medo?" e "aqui na França o nuclear é tabu" foram observações que escutei de pessoas de diversas formações profissionais e que não estavam relacionadas à minha pesquisa. Um militante antinuclear que entrevistei para a pesquisa afirmou já ter, mesmo, sofrido um atentado: “[...] jogaram um carro em cima de mim [...], cortaram várias vezes a energia da minha casa, quando eu participava mais ativamente do movimento".

15. Em vários artigos da Constituição Federal, é prevista a "participação democrática na formulação de políticas públicas", princípio administrativo que inspira a exigência de audiências públicas para licenciar empreendimentos, bem como a formação de conselhos, tais como municipais, estaduais e gestores.

16. A fala da representante do MP na audiência teve um claro caráter de denúncia e manifesta uma contradição, se não de propósitos, pelo menos com relação aos meios para atingi-los, entre o Estado que licencia (Ibama), o Estado que defende os direitos difusos (MP) e o Estado empresário (ETN). Este último conta com o apoio do governo federal, empenhado em viabilizar o Programa de Aceleração do Crescimento (PAC). Enquanto a advocacia geral da União julgou constitucional a construção de Angra 3, dispensando a manifestação do Congresso, o MP anulou, por ação judicial na justiça de Angra dos Reis, as audiências públicas ocorridas nos dias 19, 20 e 21 de junho de 2007, por terem ocorrido sem a presença de representantes do MP. O Ibama marcou novas audiências para os dias 25, 26 e 27 de março de 2008, respectivamente em Angra dos Reis, Paraty e Rio Claro (Diário Oficial da União, 25 de janeiro de 2008). 


\section{Gláucia Silva}

\section{REFERÊNCIAS BIBLIOGRÁFICAS}

ASHFORTH, Adam. (1980), "Reckoning Schemes of Legitimation: On Comissions of Inquiry as Power/Knowledge Forms". Journal of Historical Sociology, vol. 3, no 1, pp. $1-21$.

BECK, Ulrich. (1994), “From Industrial Society to Risk Society: Questions of Survival Social Structure and Ecological Enlightenment", in M. Featherstone (ed.), Cultural Theory and Cultural Change. London, Sage.

(1995), Ecological Enlightenment. Essays on the Politics of the Risk Society. Amherst, New York, Humanity Books.

. (2001), La Société du Risque. Sur la Voie d'une autre Modernité. Paris, Alto Aubier.

. (2003), Liberdade ou Capitalismo. Ulrich Beck Conversa com Johannes Willms. São Paulo, Ed. Unesp.

BEYNON, Huw. (1999), "Protesto Ambiental e Mudança Social no Reino Unido". Mana, vol. 5, no 1.

BEZERRA, Marcos Otávio. (1995), Corrupção: Um Estudo sobre Poder Público e Relações Pessoais no Brasil. Rio de Janeiro/São Paulo, Relume Dumará/Anpocs.

(1999), Em Nome das "Bases". Política, Favor e Dependência Pessoal. Rio de Janeiro, Relume Dumará.

BOLTANSKI, Luc e THÉVENOT, Laurent. (1991), De La Justification. Les Économies de la Grandeur. Paris, Gallimard.

BOURDIEU, Pierre. (2000), Esquisse d'une Théorie de la Pratique (Precede de Trois Études d'Ethnologie Kabyle. Paris, Seuil.

(2007), Meditações Pascalianas. Rio de Janeiro, Bertrand Brasil.

BOURRIER, Mathilde. (2004), Le Risque Organisationnel. Enjeux pour la Connaissance Sociologique. Trabalho apresentado para obtenção da habilitação para orientação e coordenação de pesquisas em sociologia na Universidade de Tecnologia de Compiègne.

CALLON, Michel e RIP, Arie. (1992), “Humains, Non-Humains: Morale d'une Coexistence", in J. Theys e B. Kalaora (eds.), La Terre Outragée. Paris, Autrement.

CALLON, Michel, LASCOUMES, Pierre e BARTHE, Yannick. (2001), Agir dans un Monde Incertain. Essai sur la Démocratie Technique. Paris, Seuil.

CHIVA, Isaac. (1970), "Imagination Collective et Inconnu”, in J. Pouillon e P. Maranda (eds.), Échanges et Communications. Paris, Mouton, pp. 162-168.

DEFRANCE, Jacques. (1988), “'Donner' la Parole. La Construction d'une Relation d'Échange". Actes de la Recherche en Sciences Sociales, no 73, pp. 52-66.

EWALD, François. (1992), “L’Expertise, une Illusion Nécessaire”, in J. Theys e B. Kalaora (eds.), La Terre Outragée. Paris, Autrement.

FUNTOWICZ, Silvio e RAVETZ, Jerome R. (1985), “Three Types of Risk Assessment. A Methodological Analysis", in C. Whippie e V. T. Covello (eds.), Risk Analysis in the Private Sector. New York, Plenum Press, pp. 217-232. 
(1993), "Science for the Post-Normal Age". Futures, vol. 25, no 7, pp. 739-755.

LASCOUMES, Pierre. (1994), Éco-Pouvoir. Environnements et Politiques. Paris, La Découverte.

LATOUR, Bruno. (1994), Jamais Fomos Modernos. Ensaio de Antropologia Simétrica. Rio de Janeiro, Editora 34.

. (1998), Ciência em Ação. Como Seguir Cientistas e Engenheiros Sociedade Afora. São Paulo, Ed. Unesp.

_. (2002), Reflexão sobre o Culto Moderno dos Deuses Fe(i)tiches. Bauru, EdUSC.

. (2004), Politiques de la Nature. Comment Faire entrer les Sciences en Démocratie. Paris, La Découverte/Poche.

LEITE LOPES, José Sérgio. (2006), “Sobre Processos de 'Ambientalização' dos Conflitose sobre Dilemas da Participação". Horizontes Antropológicos, vol. 12, no 25, pp. 31-64.

et alii. (2000), "Naturalização e Estranhamento: Alguns Aspectos da Construção Social da Poluição Ambiental em Itaguaí, Angra dos Reis e Volta Redonda, RJ". Cadernos IPPUR, vol. XIV, no 1, pp. 181-196.

LEITE LOPES, José Sérgio et alii. (2006), “Audiência Pública em Angra dos Reis: Debate em torno do Licenciamento de uma Usina Nuclear", in M. Palmeira e C. Barreira (orgs.), Política no Brasil: Visões de Antropólogos. Rio de Janeiro, Relume Dumará.

LEITE LOPES, José Sérgio (org.). (2004), A Ambientalização dos Conflitos Sociais. Participação e Controle Público da Poluição Industrial. Rio de Janeiro, Relume Dumará.

LÉVI-STRAUSS, Claude. (1976), "A Ciência do Concreto", in O Pensamento Selvagem. São Paulo, Ed. Nacional, pp. 19-55.

MALHEIROS, Tânia. (1993), Brasil, a Bomba Oculta: O Programa Nuclear Brasileiro. Rio de Janeiro, Gryphus.

NELKIN, Dorothy e POLLAK, Michael. (1981), The Atom Besieged: Extraparliamentary Dissent in France and Germany. Cambridge, MIT.

OLIVEIRA, Odete Maria. (1989), A Questão Nuclear Brasileira: Um Jogo de Mandos e Desmandos. Florianópolis, EdUFSC.

PRADO, Rosane Manhães. (2002), “A Beleza Traída: Percepção da Usina Nuclear pela População de Angra dos Reis". Antropolítica, no 13, pp. 137-160.

. (2003), “As Espécies Exóticas Somos Nós: Reflexão a Propósito do Ecoturismo na Ilha Grande". Horizontes Antropológicos, vol. 9, no 20, pp. 205-224.

RAVETZ, Jérome. (1992), “Connaissance Utile, Ignorance Utile?”, in J. Theys e B. Kalaora (eds.), La Terre Outragée. Paris, Autrement.

RIBEIRO, Agum. (2005), Responsabilidade Social das Empresas: Quando Apoio e Risco Caminham Juntos. Dissertação de mestrado, Universidade Federal Fluminense (UFF), Niterói.

ROQUEPLO, Philippe. (1992), “L'Expertise Scientifique, Consensus ou Conflit?”, in J. Theys e B. Kalaora (eds.), La Terre Outragée. Paris, Autrement.

SILVA, Gláucia. (1999a), Angra I e a Melancolia de uma Era. Um Estudo sobre a Construção Social do Risco. Niterói, EdUFF. 


\section{Gláucia Silva}

. (1999b), “Risco Tecnológico e Tradição: Notas para uma Antropologia do Sofrimento". Antropolítica, no 7, pp. 57-73.

. (2007), “A(Di)gestão do Risco Nuclear na França: O Caso das Comissões Locais de Informação”. Mana, vol. 13, no 2, pp. 441-470.

THEYS, Jacques e KALAORA, Bernard. (1992), “Quand la Science Réinvente l'Environnement", in J. Theys e B. Kalaora (eds.), La Terre Outragée. Paris, Autrement.

TOURAINE, Alain et alii. (1980), La Prophétie Anti-Nucléaire. Paris, Seuil.

ZONABEND, Françoise. (1989), La Presqu'île au Nucléaire. Paris, Odile Jacob. 


\begin{abstract}
Expertise and People's Participation in the Context of Nuclear Risk:

Democracy and Environmental Licensing of the Angra 3 Nuclear Power Plant
\end{abstract}

This article discusses the specificity of citizens' "participation" in contexts of decision-making on the acceptance of nuclear risk, demonstrating that such acceptance depends on mediation by professionals who are willing to translate the typical scientific jargon of technical reports and/or produce their own reports, by way of counter-expertise; otherwise, lay people are unable to confer scientific legitimacy to their arguments. The basic empirical references for the current analysis are the recurrent themes from public hearings organized for licensing of two Brazilian nuclear power plants using German technology, Angra 2 and Angra 3, with an emphasis on the latter, now undergoing prior environmental licensing. The forms of "social control" engendered in France serve as a counterpoint for developing the article's argument.

Key words: nuclear risk; people's participation; expertise

\title{
RÉSUMÉ
}

Expertise et Participation de la Population dans un Contexte de Risque Nucléaire: Démocratie et Licence Environnementale de la Centrale Angra 3

Dans cet article, on discute la spécificité de la "participation" des citoyens dans les cas de délibération sur l'acceptation du risque nucléaire, montrant que cette participation dépend de la médiation d'un professionnel capable de traduire le jargon scientifique des documents techniques ou établissant lui-même ses propres documents, à titre de contre-expertise; sinon, les profanes ne sauront légitimer leurs arguments scientifiquement. Dans ce travail, on prend comme base empirique les thèmes récurrents des audiences publiques organisées en vue du permis de fonctionnement des deux centrales nucléaires brésiliennes de technologie allemande - Angra 2 et Angra 3 -, surtout pour cette dernière, en cours de licence environnementale préalable. Les formes de "contrôle social" patriquées en France servent de contrepoint à la construction de ce qui est ici exposé.

Mots-clé: risque nucléaire; participation de la population; expertise 